\title{
大腸機能異常の臨床
}

\author{
九州大学医学部桝屋内科 \\ 池見酉次郎，井上 幹雄，福元哲四郎，他
}

\section{CLINICAL STUDIES ON FUNCTIONAL COLONOPATHY}

\author{
Yujiro IKemi,M.D., Mikio Inoue, M.D., \\ Tetsushiro Fukumoto, M.D. et. al. \\ 3rd Clinic of Internal Medicine, \\ Kyūshū University School of Medicine, Fkuoka
}

\section{1 はしがき}

欧米，とくに米国に扔いては，つとに大晹機能 異常，い和ゆるIrritable colon なる概念が臨 床上広々用いられておりここのテゴリーに属す る疾患は消化器宾患中て，そうとう大きなバー七 ントを占めることが注目されている。しかるに徝 来わ机国では，加〉西見地上りする大腸疾㭧の研 究はきわめて少なく(八田，松永，三好諸氏の報 告があるのみ)，本症に対する䛦療の方針もきわめ てあいまいである。スこでわれわれは今回かるる カテゴリーに大る大腸疾㭧がわが国でいかほどの 臨床的意義を有している办を检討し，六の診痖の 方制を古てるために次の上うな研究を行なつた。

今回の調查にあたつては，今日普通に行なわれ ている検查法によつて, 明らかな器質的病変のあ るものの除外に努好たが，加〉る除外䛦断的（negative) な行き方並行して，積極的(positive) な立場から，心理学的な柃查や機能学的な観点上 りする治療を行なつた上で, 本症の診断を行なつ た。しかしてわれわれのいう大腸機能珙常なる概 念汪，純機能的な疾罡というのではなくて，彭療 上機能学的な越置や心理的な取り报小が重要な意 義学有する症候群を意味している。

\section{2 本症の分類}

われわれは本症妾一泦第 1 表のことく命名して 分類した。今日まで本症は Functional colono-
pathy（機能的大腸症）とされていたが，Bockus もいつているょうに，本症では大腸だけでなく小 腸にも変化が見られるので, Functional enterocolonopathy 飞名づけるのが最安妥当である. その内容は腸の運動機能と分泌機能の失調であつ て, これら両因于が関与する程度によつて，表の ような病型に分かつことができるが，本質的には 同一のカテコリーに属するものと考えられる。本 症息者の過半数を占めるものは便秘あるいは便秘 下痢交替を星する不安定型に属するものである。

本症の些型的少経過第 1 表に示した。持続下 瘌型は良来一般に神経性下痢と呼ばれていたもの に相当し，主として運動機能の亢谁によるもので ある。これと不安定型の進行した時期に持結性の 下痾を呈するものとを一応区別したが，後者の方 が下痢，榎痛，粘淮の排出などの程度が強く，一 般に前者よりも難治である. 分泌型は不安定型と ほ心゙同様の発生機転に上るものであるが，粘液の 分泌が非常に著明なもの，とくに排便後粘液のみ 林單独で出るような場合をかくのごとく区别す る、これの典整的なものはかが国ではまれとさ れているが，不安筀型との移行型に属するような 例は決して少なくない。

\section{3 本症の診断法}

本症の䛦断にあたつては，まず除外的な立場名 ら符 2 表のごとき諸状態老除外するとともに， 
第 1 表. 本症候群 9 分類 (Functional Enterocolonopathy)

\begin{tabular}{|c|c|c|}
\hline 1) & 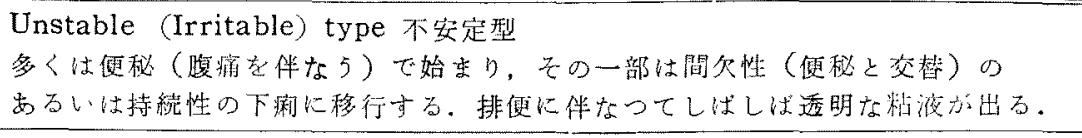 & 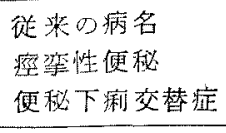 \\
\hline 2) & 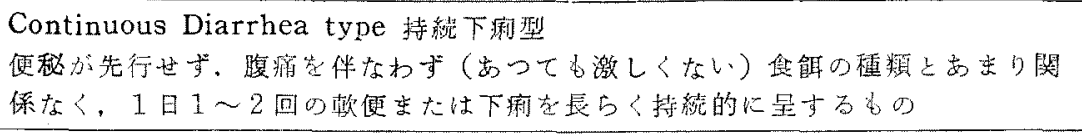 & 神程性下痢 \\
\hline 3) & 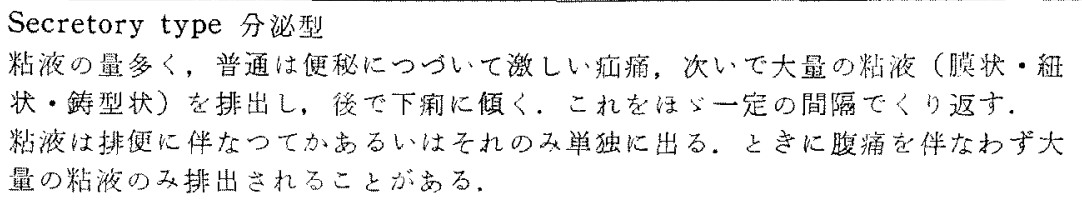 & $\begin{array}{l}\text { 粘液性大腸炎 } \\
\text { 粘液疝催 }\end{array}$ \\
\hline
\end{tabular}

籍 2 表。本应候群の䛦断

\section{1, 除外診断}

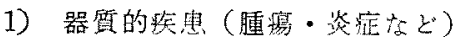

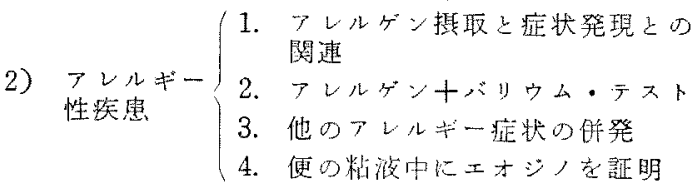

3）下剂の遠用比よるもの

4) 細菌，原虾上るもの

5) 胃性下浰

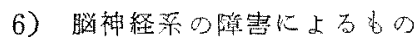

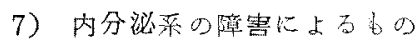

8) 消化器棌内外の蜘热に上つて二次的に执こつた \&の

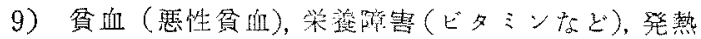
2. 陽性䛦唃

1) 間けつ性の腹耀十便通罢常

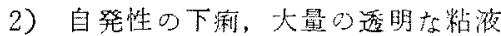

3) 精神的垊不安, 緊張分洞係

4) 白律神経，组管運勒神経の下安定の症状

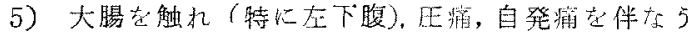

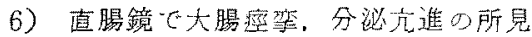
レントゲン，直腸畬検査による症状の再現

7) レントダンで小渴大晹の過敏状態(機能罢常), 通 過促進店と。

8）胃結腸原射の䒕進

positiveな立場からの診断が特に重要である。

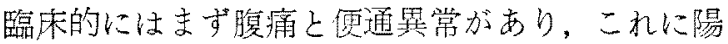
性診断の（2）以下の諸要因加加わるにつれて,

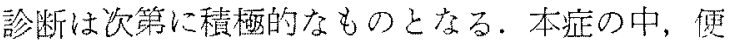
秘を主とするものと單純性便䀣との区别名大比で

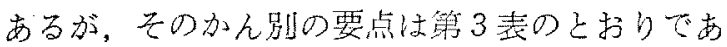
万.
本症の頻度について，われわれが 1 力月の間に 当科外来で調查した結果，一般の外来患者の約三 分の一に便通異常が見られ（便通異常を主訴とし ない場合もふくむ)，その約四分の一ないし三分の 一(便秘で約六分の一) が本症候群に属するも のと考えられた。また 5 カ月の調查期間中に外 来，入院で40例以上のこの種の患者を経験したこ とから見ても，本症はごく普通に見られる疾息で あると考えてよからう。吓のデータ一は当科で 経験した41例の本症㭧者（不安定型23，持続下浰 型16，分泌型 2$)$ についてえられたものである. われわ机は直腸鏡（ジグモイドカメラを含む），経 口および逆行性レントダン検查, 㭘便, 胃液㭘查, 胃レントダン梌查，小腸大盼の生検，自律神経機

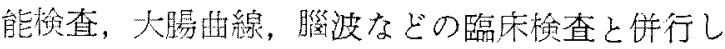
て Cornell Medical Index, 矢田部・ギルフォー ドならびに内田・クレペリンの性格㮥查，ロール シャッハテスト，面接などの心理梖査を詳細に行 なつた。

\section{4 発病の年令, 誘因など}

初発年令は若・壯年に多く，男女間に频度の差 は見られ劣かった。症状の持続期間は 1 年以上に 亘るものが多く，しばしば5〜10年に及ぶものが 見られた。また本症は文明病の最たるものとされ ているが，われわれの例でも，頭腧学働者（いわ 沙るホワイトカラ一族）に多く，肉体学㗢者に少 ない傾向が方机た。

当科に来るまでにつ㚈られていた䛦断名として 
第 3 㱔。単純性便咥之の別

\begin{tabular}{|c|c|}
\hline 本 症 䐅 群 & 路 純 姓 使 \\
\hline 1)アトロピン系統，猗位による症状の埾快 & 1)アトロビンで怪快はず，楾維住により柽快 \\
\hline 2) 便加固く，小さく，組く，量加少ない & 2)固く、大きい \\
\hline 3）自発性の下㾰，下剂に過微 & 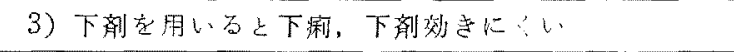 \\
\hline 4) 便秘が間不性 & 4）長期にわたり持紸性で進行性 \\
\hline 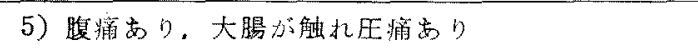 & 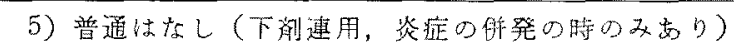 \\
\hline 6)大㻎の透明な粘滩走伴な5ことが多い & 6) 少恎い \\
\hline 7）情緒の影望が強い & 7)著明でない \\
\hline 8) 月経前に增要 & 8）著明でない \\
\hline 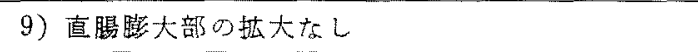 & 9) 5 \\
\hline 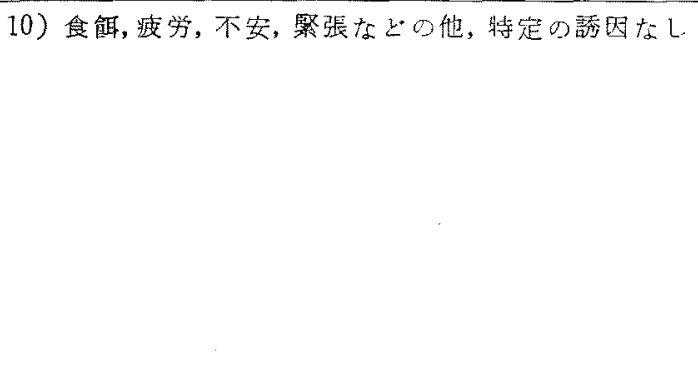 & 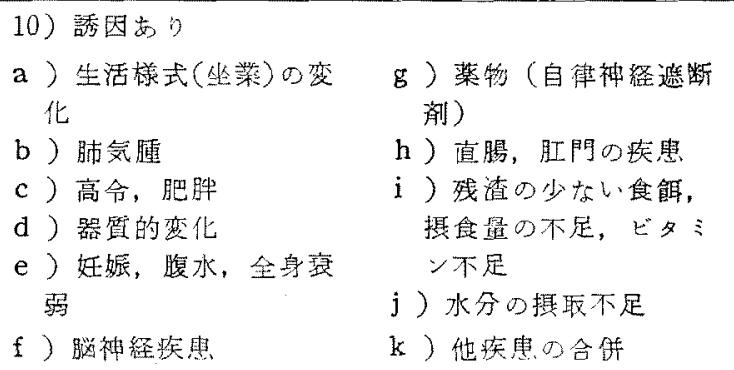 \\
\hline
\end{tabular}

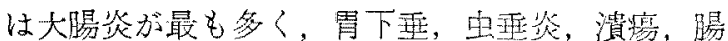
結核，胃炎，軻瘉着などさまざまであつた。手 術とくに虫垂切除の既往を有するものが多く（16 例)，この中本症発病後に手術を受けたものでは， これによる軽快がほとんどみられていない。

発病の誘因としては，精神的な不安，緊張や食 慨の過愦，これらの雨方に関俰するものなどが最 も多くみられた、本症の発生に注，刺激性の食品 や薬品による影響と，情諸的ストレスとの二つが 重要であることが欧米でも指摘されている，再 燃, 增惡の誘因としては体の椧え，冷い领物，感 冒，心身の過労，感情の变動などがとくに重要な 意味を持つていた。

\section{5 症状}

消化器症状としては, 腹痛と便通異常が必発の 症状であり，腹痛は左下腹部に最も多く(われわ れの例で約56\%）みられ，排便の前におこり，Z の後で軽快するものが多かつた。ををして上腹 部痛を件ない，そのため胃・十二指踢溃演，胆の
う症などと，五やまられるもの者あ、その他の 症状としては腹鸣，げつぷなどのガス症状や胃症 状がよみられる。

診断上とくに重要とされているのは便の性状で ある。比較的透明で非炎症性の粘液妾伴なうこと が多く，膿，血液を混ぜず，一般に便塊が小さ く，便秘の時は雭罣状あるい汢鉊筆状を呈し，軟 便の時でも小さくて細い，

さらに多年にわたる経過をとりながら，消化器 の他の器質的な疾患ぶ長びいた場合に比して，栄 盖低下，やせ，貝血などが少ないことも注意す心゙ き点である。

\section{6 レントゲン，直腸鏡などによる所見}

この場合レントゲン検查の最も大きな意義は， 器質的疾患の除外である。機能性の是秘について

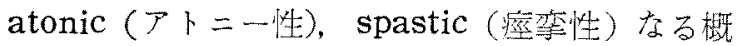
念を脟入したのは Fleinerであり，本症特に便 秘型は彼のいう spastic のタイブに属するもの のようであるが，実際問題としては，レントゲン 
でこれら耐者を明らかに区别できる場合はむしろ 少ない：また日によつて腸の緊張状態はかなり变 動するものであり，レントゲン检查を唯一の手が かりとして，本症を䛦断することはむしろ国難で ある。

われわれが行なつたレントゲン検查の結果，ま ず小腸では，粘膜像の粗大化，分節像および分泌 京進(粘液も含む)が60～70\%に認められ，次いで

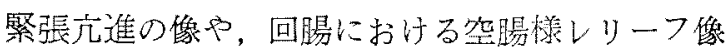
の出現なども高率に認められた。しかして，一般 にかっる異常所見は回腸に多かつた。また小腸通 過の促進を示すものが多く，不安定型，持続下涩 型を通じて約 $1 / 3$ は， 1 時間30分以内に小腸を通過 した.

これらの中18例について小渴生桧を行なつた 方，1例に蛏度の細胞漫㵎老認めたのみで，その 他の例ではレントゲンで上記のような暴常所見を 呈したものでも，病理学的には特に異常を認わな かつた。

経口的大腸X線所見では，不規則なハウストラ 像，著明な断裂像，緊張や蠕動の元進等が約半数 に認められ， string sign（パリウム排出後に粘 液に附着したバリウムによつてできる紐状像) は 3 例に認められたに過ぎない，その他著明な大腸 ガス像，分泌充進像，通過や排泄の促進などがみ られ，便秘型ではバリウムの停滞（特に横行結腸 あるいは下行結腸に）定示すものが多かつた。

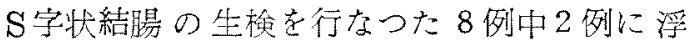
腫, 細胞漫潤が認められたが，積極的に大腸炎と は䛦断しがたい程度のものであつた。

值腸鏡䄼査もレントゲンと同じく，器質的な变 化を除外するのが主要な目的で, 本症に特有とす べき所見はえら机ない。

\section{7 病因についての考案}

われわれが不安神経症の患者20例について調心゙ たところ，10例が軟便ないし下廊を，10例が便秘 を(便秘，下莉交替のものも含めて）,12例名腹鳴 を訴えていた，しかして，不安緊張の状態で便通 異常，特に下獭を呈し，これに対して特別に沿療
を加えなくても，不安反応や心臟神経症が軽快 するとつもに，自然によくなるというようなこと は，日常われわれが経験するところである．さら によく注意してみると，功患者では，同時に

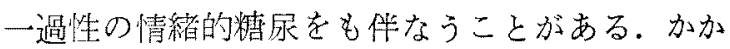
る哥夹は，本症がストレスに対する生体の全体反 応の一部として現われる可能性を示㖫している。

身体各部に打ける白律神経失調の症状 24 項目に ついて調いた結果, 本症㭧者群では正常者に比し て，こ狆らの症状訴える頻度が高かつた。また メコリールテストによつて自律神経の緊張状態を 調へた結果，そのアンバランスを示すと思われる ものが多かつたが，交感，副交感のいずれか一方 に俩しているとは結論し難い成績であつた。大腸 曲線による梭查の結果でも，必ずしも常に症孪性 でなく，緊張低下の場合もあり，概してdystonia (キストニー) と称すへきものと考えられ た。

以上の上うな事奏から，本症では自律神経の失 調が重要灰役㓶老演ずることがうかがわれるが，

Bockus などの云うように副艾感神経の過緊張に よる症状であると割り切ることには無理があるよ うである。また本症のアレルギ一説については，

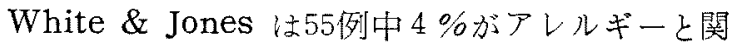
係があつたとのへ，Bockusなどもかっる例は少 ないとしている。われ和の経験でもか子る例 はまれで，はつきりアレルギー上関係のあるもの は，今回の調查から除外した。そのような例はむ しろアレルギ一性腸炎として，本症候群からは一 応区別さるい゙きものと考えられる。

\section{8 心理検査による所見}

われわれの調查では積極的に神経症的であると 思われた例は39\%であり，あまり神経症的でない 症例でも症状と感情的ストレスとの間には，かな り高度の相関が見られた。症状の初登や経過と感 情的ストレスとの相関については，第 4 表のとお りである。

次に前記の性格㛟查を行なつた結果，一般に緊 張，固熱，感情不安定の傾问の強いことがうか心゙ 
われた，便通異常を来たしたときの心理状態につ いては，緊張，心配，怒りの抑圧などが最も多 く, これについて恐怖, 不安, 葛藤, 社会的不適 応などが多いようである。

心身相関の実験として，大腸曲線をとりなが ら, 被检者を感動せしめるような話題について面 接したところ，第1図のように，ワゴスチグミン によるものと類似の反応を起こす場合のあること がわかつた。また次の第 2 図は被㭘者として雇わ れた健康な学生の空腸のレントゲン写負である が，管 1 回の検查時にはたまたま強い不安，緊張 の状態にあり，図のaのごとき異常所見を呈し た。しかるに日をかえて全く平静な時に写負をと ると，図のbのごとく，汪とんど正常な像を示し た。

さらに第 3 図は，46才の男子で 3 年前から職場
における特定の感動（主として憤まん，屈辱感） に伴なつて，下痢を起こす人のレントケ゚ン写真で ある。この㭧者を倠戥状態にして約15分間，例の 感情問題についての暗示を与えると, 四のbのご とく, 暗示前（図のa）に比べて著しい腸の運動 と緊張の亢進が見られた。さらにか>る暗示を続 けることによつて䨑際に下瘌を起こさせることが

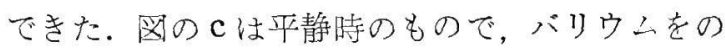
んで 3 時間半でまだ盲腸に達していない，図のd は上記の暗示を続けて与えた時のもので， 1 時間 半ですでに上行結腸に達している.

青魚，たこ，なまこ，生卵など特定の食品在と ると，きまつて惡心，呕吐，下痢を来たす人があ り, 従来かっる現象はこれらの食品に対するアレ ルギー反応によるものと考えられているようであ

第 4 表.

パーソナリティと情緒的ストレス

\begin{tabular}{|c|c|c|c|}
\hline 1) & 本症患者（41例中） & $\left\{\begin{array}{l}\text { 神経症的なむの } \\
\text { むまり神経症的でないもの }\end{array}\right.$ & $\begin{array}{l}16(39 \%) \\
25(61 \%)\end{array}$ \\
\hline 2) & 情緒的ストレスとの相関（37例中） & $\left\{\begin{array}{l}\text { 初発に関倸したもの } \\
\text { 経過に関係したもの }\end{array}\right.$ & $\begin{array}{l}22(60 \%) \\
26(70 \%)\end{array}$ \\
\hline 3) & 情緒的ストレスが特に重要な意味を有すると & 思われるおの（37例中） & $10(27 \% .0)$ \\
\hline 4) & パーソナリティと情緒的ストレスとの関係 & $\begin{cases}\text { 神経症的なもの } & 14 \\
\text { あまり神経症的でないもの23 }\end{cases}$ & $\begin{array}{l}\text { 初発 } \\
12(86 \%) 13(93 \%) \\
10(43 \%) 13(57 \%)\end{array}$ \\
\hline
\end{tabular}

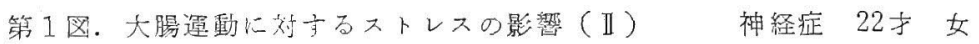
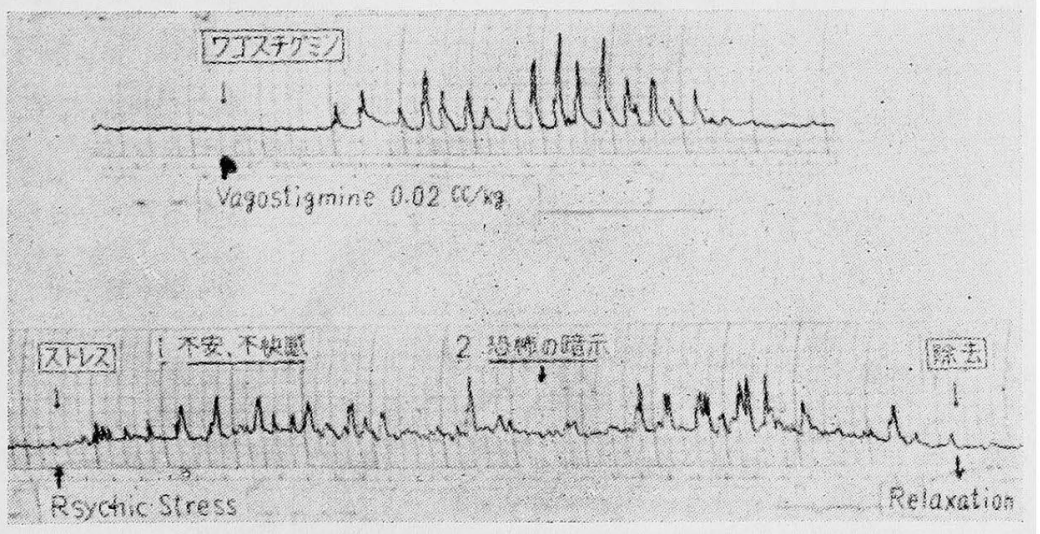
第 2 図. (a)

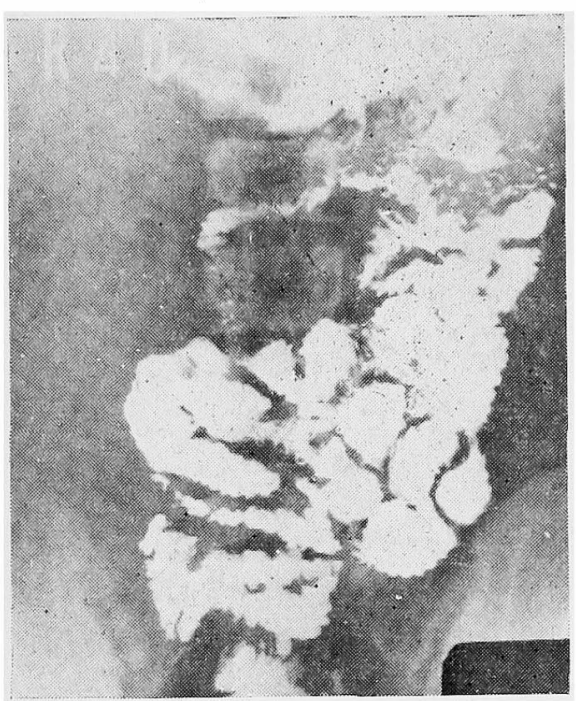

る.協同研究者の中川注，某高校の学生 350 人の 中から，明らかにか>る区応を示す19名を選び出 し，その中の 5 名について第 5 表のような奏験を 行なつた。すなわち, 被㛟者に全く普通のハリウ ムを飲ませた後で，「今のバリウムには○○の食 品が入つていた」と強く暗示したところ, 表のよ うないろいろな症状が現われた。次に笑際にバリ ウムに問題の食品を混入しておき，これを普通の
第 2 図.（b)

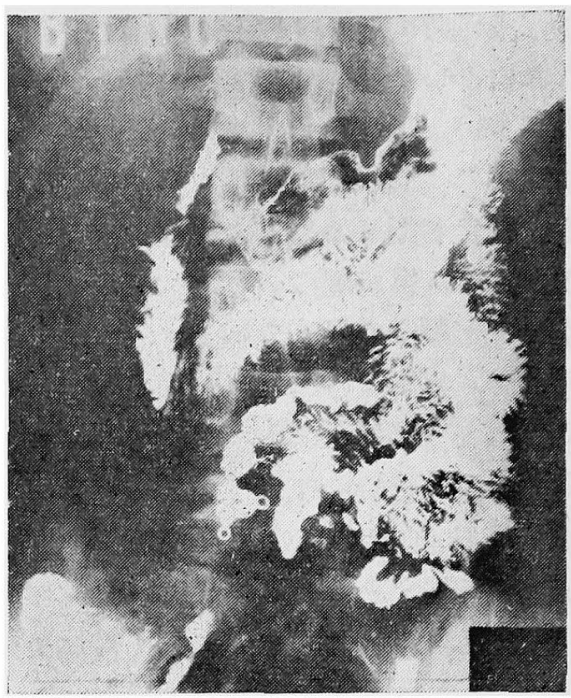

パリウムと称して飲ませた場合には汪とんど全く 症状が現われないことを知つた。まだ例数が少な いので結論的なことは言えないが、これらの 5 例 は at random に選び出されたものであり，か >る事奏はこの種の例のそうとうな数に当てはま るものと考えてよかろう。すなわちこのような例 では食品に対する恐怖心の役割を正しく評価する ことが大切である。

第 5 表. 食品アレルギーに関する心理箺験

\begin{tabular}{|c|c|c|}
\hline 被 検 者 & パリウム十暗示 & バリウム十食品 \\
\hline 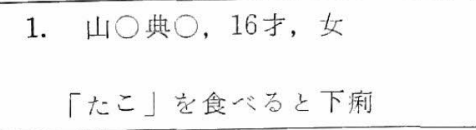 & $\begin{array}{l}\text { 恶心, げっぷ, めまい } 32 \text { 分, } \\
1 \text { 時閒40分後に軟便〜下痢 }\end{array}$ & 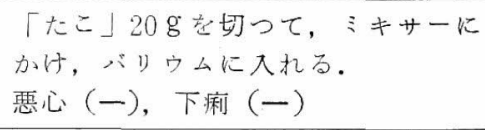 \\
\hline $\begin{array}{l}\text { 2. 佐○敬○，17才，女 } \\
\text { 「生卵」が䈐についただけでも } \\
\text { 悪心あり，食べると嘔吐 }\end{array}$ & 悪心, 湢吐 & $\begin{array}{l}\text { 「生卵」30 g 右バリウムに入れる } \\
\text { 恶心 (一)，嘔吐 (一) }\end{array}$ \\
\hline $\begin{array}{l}\text { 3. 北○雅○，17才，女 } \\
\text { 「ピーマン」「にんじん」を食 } \\
\text { ベると下痢 }\end{array}$ & 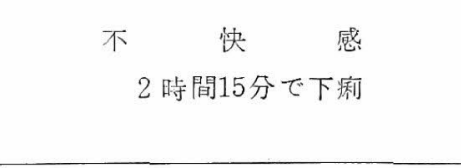 & 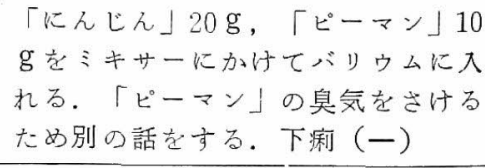 \\
\hline $\begin{array}{l}\text { 4. 井○俊○，17お，女 } \\
\text { 「なまこ」「5に」を食べると } \\
\text { 嘔吐, 下痢 }\end{array}$ & 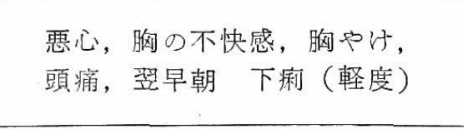 & $\begin{array}{l}\text { 「ラに」5gをバリウムに入れる. } \\
\text { 臭気を消すためココア，砂糖を加え } \\
\text { る. 嘔吐 (一), 下痢 (一) }\end{array}$ \\
\hline $\begin{array}{l}\text { 5. 山○清○郎, } 20 \text { 才, 男 } \\
\text { 「さば」を食べると下痢 }\end{array}$ & $\begin{array}{l}\text { 德心, 腹部不快感バリウムの通過 } \\
\text { 促進 } 2 \text { 時間で下痢 } 2 \text { 回 }\end{array}$ & \\
\hline
\end{tabular}


第 3 図. (a)

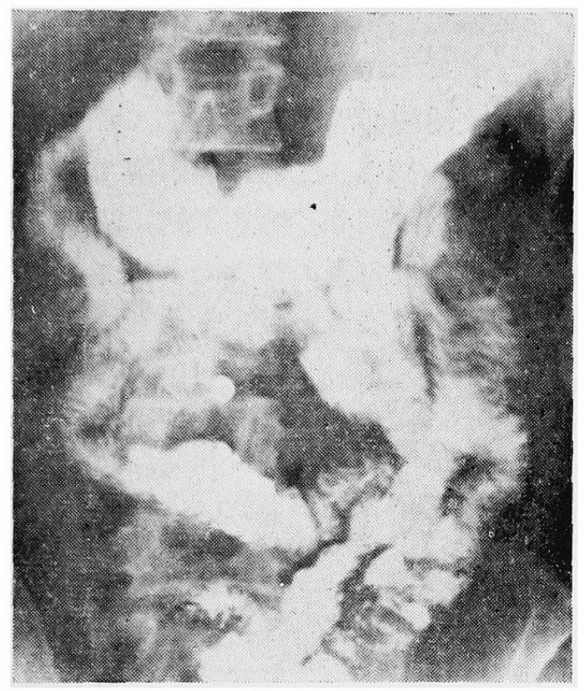

第 3 図. (b)

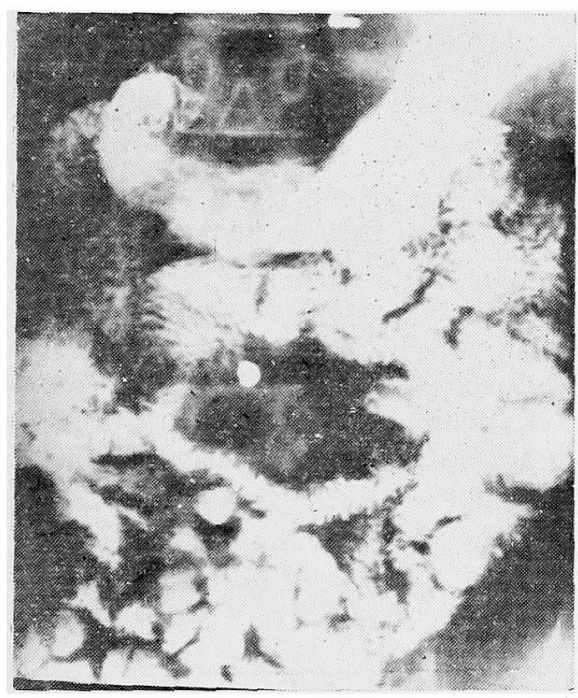

\section{9 治療の実際}

Bockus ほ「本症ほどその治療に医師の忍耐と 挍倆を要する疾患はない」とのぺている。

（1）心理的な処置、患者はしばしば癌その他 の重篗な器質的疾患ではないかと心配しており， なるべく徹底した検查を行なうことは器質的な病 变を除外できるだでなく，精神療法的な意味も 大きい、また医師自身が本症についての充分な理 解をもち，確乎たる態度をもつて，患者の治療に
第 3 図. (c)

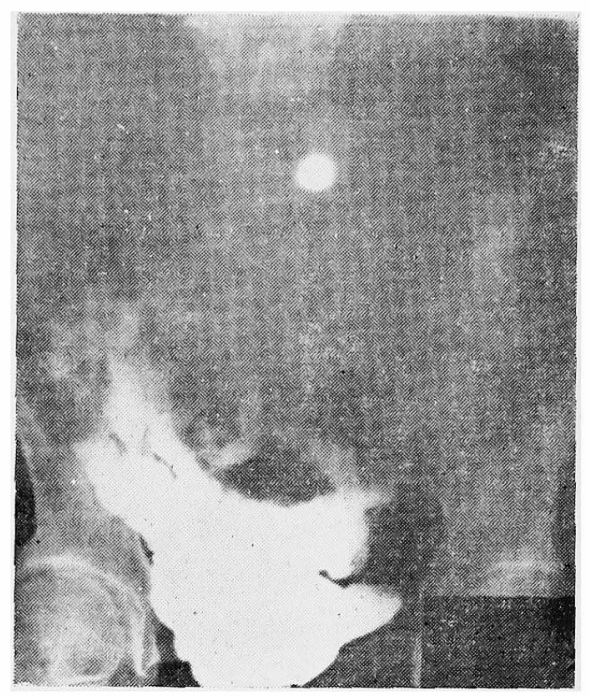

第 3 図. (d)

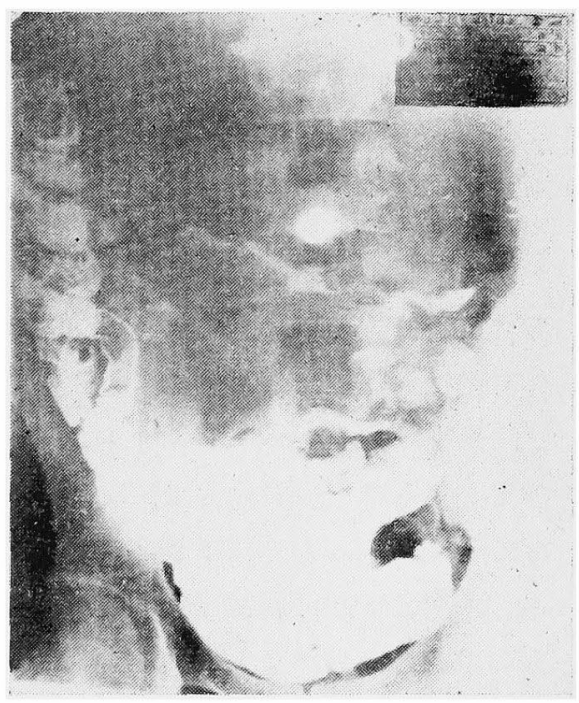

当たることが特に大切てある。

患者に, 病気の本態をよく理解させて, 精神的 な支持を与えることは最も大切な点であり，これ

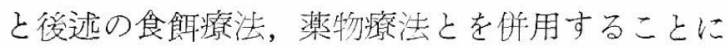
よつて, 多くの症例㤎全治ないしは著しく軽快す る。しかし実際に患者が当面している種々の感情 問題に対して，しかるべき処置を行なうことも， しばしば必要である。

（2）生活指導。過学すると症状の亞然が起こ 
るので，徐マに骤動を課し，適当な睡眠（普通の 人ょりも多々眠ることが必要であり，千睡なども よい)，休盖をとらせる功よい，食想慣を正しくす ることが特に大切であり，胃結晹反射による大晹 の道動汃規則正しく起こるようにさせる。

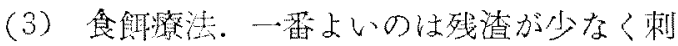
激の少标い，柔くて消化しや古い食物のリストを 婜皆に一え，因類はミンチとし，野菜はなるべく 筷ごにしてとるようにす〉めることである。こ

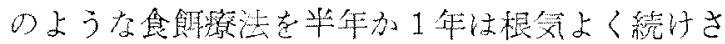
せる心要がある。

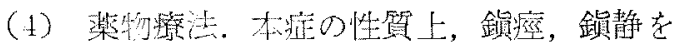

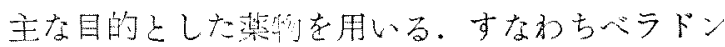
ナ、アトロピンその他の自律神経选断詴(ファイ ナリン, ハンサイン，プスコパン，プロバンサイ ン，トロピンなど)にフェノバルビタール，ブロ 一ム、種々のトランキライザ一、コデインなどを

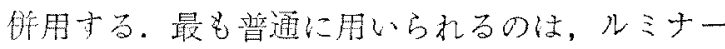
ル，ロートエキスおのおの0.06，0.10合都で，

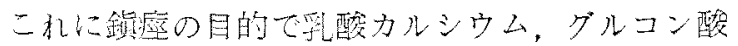

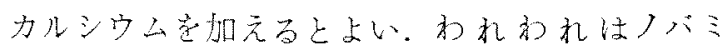
ン，ヘレルガールの併用もよく行なう。

これらの含绪は，一般に食前15３0分に用いる

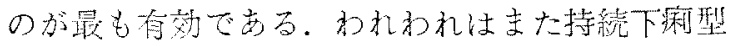
や分泌整にフォイナリン，バンサイン，プロバン サインを用いてしばしば良效をえている。その注 か圭分なビタミン刷，とくにビタミンB剂を投与

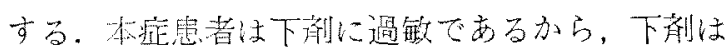
原則上して用いない力かよい。

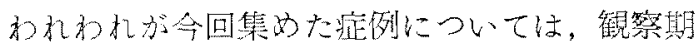
閒方短いので，結碖的なことは申し上沙られない
が，以上のごとき処置によつて，70〜80\%估は治 痹ないし柽快しつかある。

\section{0 むすび}

いわゆる大腸機能暴常について，詳細な臨床的 微察索行なつた結果，本症はわが国でもごく普通 に見られるものであり，機能学的，臨床心理学的 立場よりする治療方針の確立によつて，著しく治 療成結索问上させることができるものであること を知つた。

\section{協同研究者}

（九州大学医学部桝屋内科；小川滋，福元措四郎，中

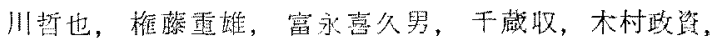

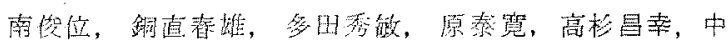

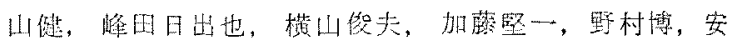
松昭道, 高虞和于.

九州大学医学部䅸神科; 雪竹朗, 大陑宝尘会病院; 中川候二.)

$$
\left(\begin{array}{l}
\text { 昭和 } 35 \text { 年 } 11 \text { 月 } 23 \text { 日 } \\
\text { 第63回九州地方会推䈍}
\end{array}\right)
$$

\section{参考文献}

1) Alvarez, W.C.: Neuroses (1951), W.B. Saunders Co. - 2) Almy, T.P.: Alternations in colonic function in man under stress, Gastroenterology Vol. 12, No. 3, Vol. 15, No. 1. -3) Grace, W.J.: Human colon (1951), Paul B. Hoeber, Inc, -4) Bockus, H.L.: Colonic neuroses, Gastroenterology (1953), W.B. Saunders Co. - 5) White, B., Stanley Cobb, S. \& Jones, C.M.: Mucous colitis, Psychosomatic medicine monograph. 一6) 池見西次郎：胃渴神経症の猃断

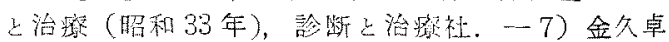

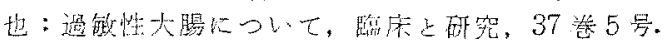
-8）八田秋：大腸逗動失調庭 "Dystonia Colica"

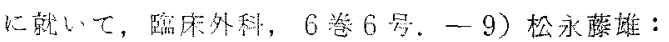

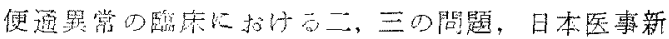

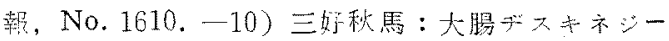

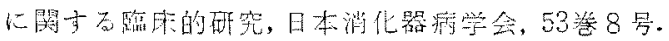

